DE

\title{
Representations of Ebola and its victims in liberal American newspapers
}

\author{
Dita Trčková \\ Tomas Bata University in Zlín, Czech Republic
}

\begin{abstract}
Combining critical discourse analysis and the cognitive theory of metaphor, the study analyses hard news on Ebola from two American newspapers of a liberal political orientation, The New York Times and The New York Daily News, to investigate metaphoric representations of the disease and portrayals of its victims. It is revealed that both newspapers heavily rely on a single conceptual metaphor of EBOLA AS WAR, with only two alternative metaphors of EBOLA AS AN ANIMATE/HUMAN BEING and EBOLA AS A NATURAL CATASTROPHE employed. All three metaphoric themes assign the role of a culprit solely to the virus, which stands in contrast to non-metaphoric discursive allocations of blame for the situation in Africa, assigning responsibility mainly to man-made factors. African victims tend to be impersonalized and portrayed as voiceless and agentless, rarely occupying the role of a "fighter" in the military metaphoric representation of the disease, which runs counter to the findings of recent studies detecting a change towards a more positive image of Africa in the media. Both newspapers fail to represent infected ordinary Africans as sovereign agents, hindering readers from reflexively identifying with them.
\end{abstract}

\section{Keywords}

Ebola, liberal American newspapers, critical discourse analysis, metaphoric conceptualizations, victims, reflexive identification, distant suffering.

\section{Introduction}

The outbreak of Ebola that began in West Africa in March 2014 was the subject of continuous widespread media coverage. Although not a major cause of mortality in humans in comparison with other illnesses such as influenza, Ebola has gained a reputation as a killer disease, in large part because it has one of the highest fatality rates among known viruses (Smith, 2006). The current strain of Ebola species has a fatality rate of approximately 55 percent (Meyers, et al., 2015). It is transmitted through direct contact with blood or bodily fluids of infected patients or animals (Smith, 2006; Meyers, et al., 2015). The symptoms include fever, headache, nausea, vomiting and diarrhoea, with profuse bleeding occurring in later stages of the illness (Smith, 2006; Meyers, et al., 2015).

Media constitute one of the main means through which the Western audience learns about and understands Ebola. They supply Western recipients with conceptualizations of the disease and portrayals of distant suffering. The present study aims to investigate metaphors of the Ebola virus and discursive representations of Ebola victims employed in two American newspapers of a liberal political orientation. The ultimate goal of the research is to reveal whether Ebola victims, most of whom have been from West Africa, are portrayed in a way that allows readers of the studied newspapers to reflexively identify with them.

\section{Theoretical backgrounds}

1.1 Critical discourse analysis and the cognitive theory of metaphor

The methodology employed in the research combines critical discourse analysis (CDA) (Fairclough, 1992; van Dijk, 1993; Weiss and Wodak, 2003; Wodak and Meyer, 2009) and 
the cognitive theory of metaphor (Lakoff and Johnson, 1980; 1999). Despite being a heterogeneous school, CDA shares common goals, namely an investigation of the constructive effects of discourse and explicit and implicit power relationships as manifested in language, and an orientation towards social problems. The cognitive theory views metaphor as an inherent part of the human conceptual system, i.e., an important tool by which humans conceptualize everyday reality. It defines metaphor as a mapping of structure from the source conceptual domain into the target conceptual domain, based on the correlation of human experience in the two domains. Recently, an emphasis on the incorporation of cognitive studies into CDA, combining examinations of ideological textual patterns and conceptualizations, has been advocated by a number of scholars (Wodak, 2006; Hart and Lukeš, 2007; Hart, 2011 ). Wodak (2006) emphasizes the importance of cognitive studies in accounting for the mediation between discourse and society, pointing out that the processes of text production and comprehension depend on available cognitive models and frames, which can be responsible for the reproduction of stereotypes and prejudices. The synergy between CDA and cognitive studies has been adopted mainly in metaphor studies (Charteris-Black, 2004; Koller, 2004), which view metaphorical linguistic expressions as materializations of ideologically embedded metaphorical concepts.

Previous research investigating metaphors in media representations of severe diseases has revealed the prevalence of militaristic metaphors, depicting the disease as an "invader" and an "enemy" and the attempts to reduce mortality from the disease as a "fight", a "struggle" and "war". Such metaphors have not been restricted to media discourse but have commonly been employed in science, medicine and policy (Larson, Nerlich and Wallis, 2005). Sontag (1978; 1989) was among the first scholars who pointed out a wide-spread, war-like, metaphoric portrayal of cancer and AIDS. Since then, inspired by Sontag's findings, a number of studies confirmed the presence of metaphors of war in discourse on cancer (Clarke, 1992; Camus, 2009), AIDS (Patton, 1990; Sandahl, 2001) and other diseases, including foot-and-mouth disease (FMD) and H1N1 (Larson, Nerlich and Wallis, 2005).

Sontag criticizes the use of such metaphors for demonizing the disease, which makes patients feel ashamed and can lead to their stigmatization, since the attribution of fault is inevitably extended to them. As a result, a number of researchers have called for the use of less problematic alternative metaphoric framings (Larson, Nerlich and Wallis, 2005). On the other hand, Sontag's work has itself been criticized for basing conclusions primarily on the author's personal experience, not providing empirical evidence proving that the employment of militaristic metaphors leads to patients' feelings of shame (Clow, 2001). Furthermore, a number of scholars have indicated positive implications of the metaphor of DISEASE IS WAR, such as its potential to serve as a source of empowerment if the patient is portrayed as a fighter (Reisfield and Wilson, 2004). In addition, Petsko (2001) claims that the metaphoric declaration of "war on cancer" has helped to obtain the necessary funding for investigations into the illness.

Apart from the metaphor of war, other metaphoric themes have been indicated to be present in the media coverage of diseases. Camus's (2009) study uncovers ten metaphors of cancer employed in scientific popularization articles in the British press, including CANCER AS A MACHINE, DIRT and A PUZZLE and CANCER CELLS AS HUMAN BEINCS and ANIMALS. The author explains the adoption of a multiplicity of metaphors as necessitated by the complexity of cancer. Wallis and Nerlich's (2005) study on the portrayal of SARS in British newspapers reveals an absence of war metaphors and their replacement by the metaphor of SARS AS A KILLER. The authors explain the absence of a military portrayal by the fact that the coverage of the disease coincided with the coverage of war in Iraq, with newspapers aiming to provide distinct discursive framings of the two events, by the lack of proximity of SARS to British readers and the government wanting to avoid panic, and by the lack of optimism that the disease will be eradicated and that the efforts would end in complete victory. As the authors assert, the absence of the military portrayal of SARS in the UK press proves that the metaphor of DISEASE AS WAR is not only a cognitive device but also a political and cultural tool.

The present study aims to continue in the research outlined above, filling the void of empirical studies on metaphoric portrayals of the current strain of Ebola. It examines whether alternative metaphors to the 
military one are adopted in the analysed newspaper discourse and focuses on the exposure of the underlying ideologies of the employed metaphors.

\subsection{Previous research on Western media coverage of Africa}

As most Ebola victims have been from West Africa, the present study is concerned with the image of the African continent provided by the studied newspapers, thus contributing to previous research on Western media depictions of Africa. For much of the 20th century, Western news media employed a colonial portrayal of Africa as the "Dark Continent", with an embedded racist ideology (Hawk, 1992). Such a portrayal depicted Africans as violent, conflictual, backward, poor and helpless. It provided an image of Africa as "a place of death, disaster, disease, and despair" (the so-called "four Ds of the African apocalypse") (HunterGault, 2006, p. 107). The representation of Africa as the inferior Other served to justify colonial exploitation (Said, 1978); as Ibelema (2014, p. 167) aptly asserts: "The quest to redeem the helplessly primitive Africans became the humanitarian rationale for colonization."

The adoption of a negative portrayal of Africa continued in the era of economic neoliberalism (De B'Béri and Louw, 2011), with, for instance, Golan's (2008) study showing that the majority of stories covering Africa on US television in the period between 2002 and 2004 were concerned with negative topics. African conflicts have often been explained by the media as resulting from primordial tribalism, with political and economic factors ignored and the West positioned as superior, devoid of any responsibility (Fair and Parks, 2001; Hammond, 2007), occupying the role of saviour (Brookes, 1995; Trčková, 2014). African sufferers have been shown to be generally depicted in the Western media as voiceless, agentless and helpless (Fair, 1996; Fair and Parks, 2001).

Yet, a number of recent studies detect a change in the media's portrayal of Africa. Ibelema's (2014) research on US press coverage of three major African conflicts in the period between 2000 and 2012 shows an absence of framing based on primordial tribalism and an inclusion of political factors to explain the conflicts. Nevertheless, Ibelema points out that the notion of otherness prevails in the coverage. Scott's (2009) analysis of representations of Africa in UK newspapers reveals that the numbers of negative and positive topics are nearly equal and that most of the negative frames stereotypically associated with Africa, including that of Africa as a place of darkness, are absent. Similarly, Nothias's (2014) study on Africa's media image in British, French and US news magazines reveals a shift towards a positive and optimistic discursive portrayal of Africa. Nonetheless, the author criticizes the representation for providing an essentialized and fantasized view of the continent, assessing its progress mainly with respect to economic performance. Ibelema, Scott and Nothias account for a change in the discursive portrayal of Africa by more enlightened reporters who are reflexively concerned about Africa's media portrayal and show more sensitivity to language. The goal of the present study is to investigate whether the shift away from a stereotypically negative discursive depiction of Africa can also be traced in the studied articles on Ebola.

\subsection{Mediation of distant suffering}

The present study relates the analysis of metaphoric conceptualizations of Ebola and discursive representations of Ebola victims to recent research on mediation of distant suffering (Boltanski, 1999; Chouliaraki, 2006; Silverstone, 2007). Such research is concerned with the role of media in positioning the audience with respect to distant sufferers, investigating under which conditions media have the potential to construct a cosmopolitan identity for the news recipient. In other words, it discusses what kind of discursive representations of distant suffering in media enable the reduction of moral distance between news recipients and sufferers.

The present study draws mainly upon the concept of "a relationship of reflexive identification" (Chouliaraki, 2006, p. 157), asking whether discursive representations in articles on Ebola allow for the construal of such a relationship between readers and sufferers. Among the necessary requirements for the establishment of a relationship of reflexive identification are a representation of sufferers as "sovereign agents," an evocation of the readers' sharing the same humanity with victims, and an engagement with the suffering of victims on both an emotional and a rational impersonal level, allowing for both empathy and contemplation (Chouliaraki, 2006). 
As a reaction to criticism of Boltanski's (1999), Chouliaraki's (2006) and Silverstone's (2007) research for not supporting the provided theory by audienceoriented empirical research, a number of recent studies on mediated suffering (Engelhardt and Jansz, 2014; Scott, 2014; Kyriakidou, 2015) focus on the audience reception of the portrayals of distant suffering. The lack of such an audiencefocused investigation in the present study is its partial limitation. Nevertheless, a textoriented analysis is beneficial on its own since, even though the interpretation process of readers is not fully determined by the text itself but also by readers' ideologies, beliefs and values (Macdonald, 2003), the provided discursive representations constrain the range of potential interpretations and reader positions (Fairclough, 1995).

\subsection{Data and method}

The sources of data are two daily American newspapers with a liberal bent: a broadsheet newspaper, The New York Times (NYT), and a tabloid newspaper, The New York Daily News $(N Y D N)$. Due to their political orientation, it might be expected that their coverage of West African countries is less patronizing than coverage provided by the conservative press. The corpus consists of hard-news articles published in 2014 (i.e., covering the time span from 25 March to 31 December), collected from the online archives of the two newspapers. The search was conducted by entering the keyword "Ebola" and was confined to articles in the "World" and "Health" sections only, with the result of 1719 hits in The New York Times and a disproportionately lower 307 hits in The New York Daily News. News stories the main topic of which did not concern Ebola were disregarded. The corpus comprises a remaining 282 articles in The New York Daily News (with the total word count of 168464 ) and 218 articles published in The New York Times (with the total word count of 180 198 ), chosen randomly to cover evenly the studied period and provide a similar total word count to the one of the tabloid newspaper.

All 500 articles were read and analysed manually by the author of this study. Firstly, drawing on the cognitive theory of metaphor, metaphorical linguistic expressions referring to Ebola were searched for. Then, underlying conceptual metaphorical themes manifested in the metaphorical expressions were traced and their rhetorical and ideological dimensions examined. Secondly, the employment of the WARRIOR iconography, i.e., the allocation of the roles of VILLAIN, VICTIM and HERO to social actors (Hawkins, 2001), was investigated. Drawing on the previous research on Western media coverage of Africa (see section 1.2), the author explored to whom the role of culprit is ascribed, namely whether the blame for the spread of Ebola is stereotypically assigned to Africans and their customs or whether political and economic factors are included to account for the situation. The author analysed characteristics and actions recurrently ascribed to Africans, examining whether any negative stereotypical portrayals of the Third World are reproduced. Then, adopting van Leeuwen's (2008) categorization system, a focus was placed on the discursive representations of Ebola victims, exploring which victims are foregrounded, and whether activation, individualization and personalization are adopted with regard to victims, allowing for their depiction as sovereign agents with whom readers can engage, a necessary prerequisite for the construal of reflexive identification between readers and sufferers (see section 1.3). Finally, social actors to whom heroic characteristics were allocated were examined.

Due to globalization, which presumptively leads to "an increased perception of shared experience" (Ibelema, 2014, p. 173), due to a heightened self-reflection and the enlightenment of Western journalists with regard to Africa's media image (Nothias, 2014), and due to the liberal orientation of the studied newspapers, the present study hypothesizes that the analysed articles abstain from negative stereotypes associated with Africa and from portrayals of African Ebola victims as voiceless and agentless.

\section{Analysis of the data}

Before a discussion of the findings, it is necessary to point out that quite a large number of the studied articles use the international news agencies the Associated Press and Reuters as sources, namely 30 percent of the articles from The New York Times and 20 percent of the articles from The New York Daily News are copies from the news agencies. This confirms Joye's (2010) claim that media tend to rely on agency reports in their coverage of foreign events, mainly to reduce production costs. 
Nevertheless, since the majority of the articles are written by the newspapers' correspondents, and, as asserted by van Dijk (1988), news agency reports are edited by the newspapers so that they comply with the newspapers' specific stylistic and political requirements, the discovered discursive patterns in the data can, at least partly, be ascribed to the two newspapers themselves.

\subsection{Metaphoric conceptualizations of Ebola}

This part investigates the metaphoric themes of Ebola recurrently adopted in the data, disregarding idiosyncratic metaphoric representations of the disease. The analysis reveals that the articles in both newspapers heavily rely on a single conceptual metaphor: the metaphor of EBOLA AS WAR. Two other metaphoric conceptualizations repeatedly found across both newspapers, yet not as frequently as the military one, include EBOLA AS AN ANIMATE/HUMAN
BEING and EBOLA AS A NATURAL CATASTROPHE.

\subsubsection{Ebola as war}

Counter to the voices calling for alternative metaphors of diseases to the military one (see section 1.1), EBOLA AS WAR remains the most prevalent metaphoric theme in the studied newspaper articles. The attempts to contain the Ebola outbreak tend to be portrayed as a waging of war against an aggressive enemy. Military material processes recurrently ascribed to people include fight, combat, battle and struggle, while the Ebola virus is depicted as attacking, invading, launching an onslaught on, pounding, battering and killing people. Common verbal materializations of the conceptual metaphor of EBOLA AS WAR and examples found in the corpus are listed in Table 1.

\begin{tabular}{|c|c|}
\hline aggressive & $\begin{array}{l}\text { Ebola is an aggressive virus that causes high fevers. (NYT, } 3 \text { September } \\
2014 \text { ) }\end{array}$ \\
\hline army & $\begin{array}{l}\text { The main United Nations health agency could not quickly muster an army of } \\
\text { experts and health workers to combat an outbreak overtaking some of the } \\
\text { world's poorest countries. (NYT, } 3 \text { September 2014) }\end{array}$ \\
\hline assault & $\begin{array}{l}\text { The latest scourge, Ebola, is under assault here in a cluster of cobalt-blue } \\
\text { buildings. (NYT, } 7 \text { October 2014) }\end{array}$ \\
\hline attack & $\begin{array}{l}\text { Ebola has no boundary, it goes anywhere and attacks anytime. (NYDN, } 10 \\
\text { October 2014) }\end{array}$ \\
\hline battle & $\begin{array}{l}\text { [...] to battle a disease that has now infected more than } 7,000 \text { Africans. } \\
\text { (NYT, } 8 \text { October 2014) }\end{array}$ \\
\hline beat & $\begin{array}{l}\text { [...] the U.S. can beat the disease if it remains vigilant. (NYDN, } 24 \text { October } \\
2014)\end{array}$ \\
\hline bomb & Ebola was like a bomb. (NYT, 13 November 2014) \\
\hline combat & $\begin{array}{l}\text { But Hickox, 33, who volunteered to work in West Africa to help combat the } \\
\text { epidemic [...]. (NYDN, } 29 \text { October 2014) }\end{array}$ \\
\hline defeat & $\begin{array}{l}\text { [...] supplies needed to help defeat the disease [...]. (NYT, } 3 \text { September } \\
2014)\end{array}$ \\
\hline defense & $\begin{array}{l}\text { [...] another necessary line of defense against this epidemic [...]. (NYDN, } 8 \\
\text { October 2014) }\end{array}$ \\
\hline enemy & Ebola is a formidable enemy. (NYT, 21 November 2014) \\
\hline field & $\begin{array}{l}\text { International medical organizations have deployed experts to the field in an } \\
\text { attempt to contain the outbreak. (NYDN, } 25 \text { July } 2014 \text { ) }\end{array}$ \\
\hline
\end{tabular}




\begin{tabular}{|c|c|}
\hline fight & $\begin{array}{l}\text { West Africa leaders have declared extraordinary measures to fight the } \\
\text { disease. (NYT, } 4 \text { August } 2014 \text { ) }\end{array}$ \\
\hline front lines & $\begin{array}{l}\text { His group, which has been battling the disease on the front lines, declared } \\
\text { the Ebola epidemic out of control in Sierra Leone and its West African } \\
\text { neighbors. (NYT, } 4 \text { August 2014) }\end{array}$ \\
\hline invade & $\begin{array}{l}\text { The Ebola outbreak has surged through porous borders to invade } \\
\text { neighboring countries. (NYT, } 31 \text { July 2014) }\end{array}$ \\
\hline killer & $\begin{array}{l}\text { The children are being monitored for symptoms of the killer virus while } \\
\text { they're quarantined at home. (NYDN, } 6 \text { October 2014) }\end{array}$ \\
\hline onslaught & $\begin{array}{l}\text { Monrovia is the first city to face the full onslaught of Ebola. (NYT, } 3 \\
\text { September 2014) }\end{array}$ \\
\hline struggle & $\begin{array}{l}\text { As West Africa struggles to contain the biggest ever outbreak of Ebola [...]. } \\
\text { (NYDN, } 4 \text { September 2014) }\end{array}$ \\
\hline war & $\begin{array}{l}\text { The Liberian military's chief of staff has suspended all other training and } \\
\text { exercises so that he can throw his entire army into the war against Ebola. } \\
\text { (NYT, } 11 \text { October 2014) }\end{array}$ \\
\hline
\end{tabular}

Table 1 - Verbal materializations of EBOLA AS WAR metaphor

The employment of the military metaphor in the portrayal of the Ebola virus is not surprising as war framing is prevalent in Western conceptualizations of aspects of human experience that involve danger and difficulties (Semino, 2008). Highly emotionally loaded, the war metaphor might have the potential to encourage people to provide aid to affected countries, as discussed by Petsko (2001). Yet, at the same time, the emotional charge may hinder a rational, matter-of-fact approach to the disease.

As pointed out by Camus (2009, p. 478$)$, the war metaphor has the potential to restore to "sufferers the power and aggression that serious illnesses take away from them." For the empowering potential of the military metaphor to be fulfilled, Ebola victims need to be ascribed agency in the fight. A quantitative analysis of the agents of military material processes (namely fight, battle, struggle, beat, defeat and combat - in both noun and verb form) has been conducted in the data (the results are presented in Table 2 ). The analysis shows that both newspapers ascribe the role of "fighter" most frequently to health workers (amid the deadliest Ebola virus outbreak in history, doctors are fighting the disease (NYT, 27 July 2014).

\begin{tabular}{|ll|ll|}
\hline New York Times & & New York Daily News \\
\hline health workers & 26 & health workers & 33 \\
country (e.g., Liberia) & 13 & Ebola patients & 20 \\
drugs/medical supplies & 9 & drugs & 18 \\
Ebola patients & 7 & country (e.g., Liberia) & 15 \\
the UN & 5 & the immune system & 5 \\
government & 4 & the United States & 5 \\
international officials & 3 & American troops & 3 \\
leaders of the affected & 3 & the WHO & 3 \\
country & 3 & & \\
soldiers & 3 & & \\
the United States & 3 & & \\
American troops & 3 & & \\
the WHO & & & \\
\hline
\end{tabular}

Table 2 - Social actors in the agentive role of military material processes and the number of their occurrences (only those social actors who occur in the agentive position of military material processes at least three times are taken into account) 
The number of occurrences of Ebola patients in the agentive role in The New York Times is more than three times lower than the number of occurrences of health workers in such a role. Out of the seven cases, one concerns a UN employee infected by the virus, three concern infected doctors and the remaining three concern ordinary African citizens (for 15 days, he [Mr. Dunbar] stayed at John F. Kennedy Hospital in Monrovia, fighting the disease, 4 October 2014). The number of cases of Ebola patients depicted as "fighters" is much higher in The New York Daily News; yet, only five of them concern an African victim (who has travelled to the United States) while the remaining fifteen concern American healthcare workers who have become infected while helping in Africa and are being treated in the United States. Both newspapers thus minimally ascribe agency in the fight to ordinary African patients.

The role of "fighter" is also commonly attributed to the country from which Ebola victims come (Liberia battled on Tuesday to halt the spread of the Ebola disease [NYDN, 19 August 2014]), reflecting a typical warlike situation (where countries wage a war), portraying the Ebola virus as a national enemy. Quite a prominent role is played by drugs (they hope to use it to develop a drug that would fight all five known strains of the disease [NYDN, 10 October 2014]), the high occurrence of which in The New York Daily News is likely due to the fact that most articles on Ebola in this newspaper are included in the "Health" section. The focus on the United States and American troops as agents in the fight in both newspapers (White House orders 3,000 U.S. troops to fight Ebola in Africa [NYDN, 16 September 2014]) may not be surprising considering the news value of cultural proximity, according to which the involvement of the US actors makes an event in a remote country more newsworthy to American readers (Harcup and O'Neill, 2001). At the same time, it contributes to the positive portrayal of the United States as saviour.

\subsubsection{Ebola as an animate/human being}

The Ebola disease is repeatedly personified in the newspaper discourse (see Table 3). It is ascribed negative, demonizing human emotions and characteristics, including anger, aggression, violence and cruelty, as in: how furiously the disease can spread; the silent but aggressive sickness; such a virulent disease; Ebola came violently; the disease had been ruthless; merciless virus; and this evil virus. Such a portrayal helps to construct the image of Ebola as an enemy and is partly subsumed in the military metaphor discussed above. Other personifying lexis in the data include a number of verbal process, such as the depiction of Ebola as running into, going away, coming back, stalking the city, lurking and refusing to go away, and the portrayal of Ebola as an unwelcome passenger.

\begin{tabular}{|l|l|l|}
\hline & \multicolumn{1}{|c|}{$\begin{array}{l}\text { New York } \\
\text { Times }\end{array}$} & $\begin{array}{l}\text { New } \\
\text { York } \\
\text { Daily } \\
\text { News }\end{array}$ \\
\hline $\begin{array}{l}\text { ascription of } \\
\text { emotions }\end{array}$ & 13 & 5 \\
\hline $\begin{array}{l}\text { personifying } \\
\text { verbal processes } \\
\text { (not counting } \\
\text { military verbal } \\
\text { processes) }\end{array}$ & 20 & 22 \\
\hline
\end{tabular}

Table 3 - Number of occurrences of personifying lexis with reference to Ebola

On one hand, the adoption of personification enables a comprehension of a not wellknown disease in terms of familiar characteristics and actions. On the other hand, the ascription of negative attributes and the demonization of the Ebola virus contribute to the stigmatization of the disease and are likely to spread fear and panic among the public.

\subsubsection{Ebola as a natural catastrophe}

The third metaphoric theme recurrently employed in the newspapers' portrayal of Ebola uses a NATURAL CATASTROPHE, most frequently a TSUNAMI/FLOOD and a FIRE (see Table 4), as the source domain. The image of water is evoked, for instance, by the depiction of the disease as a deadly tide that swept through, as coming in waves and as spilling over borders. The metaphor of a FIRE, illustrated in example (1), is materialized in expressions including the disease has spread like wildfire, hot spots where the disease is smoldering, we need to extinguish it and the outbreak has burnt out. The idiosyncratic examples of metaphors of a STORM and an EARTHQUAKE are adopted in witnesses' accounts of Ebola, reproduced in examples (2) and (3).

(1) We cannot cut off the affected countries and hope this epidemic will simply burn out. 
To put out this fire, we must run into the burning building. (NYT, 8 September 2014) (2) In the last six months we have been witnessing what can be described as a perfect storm - everything is there for it to snowball. (NYT, 26 August 2014)

(3) Ebola is like having an earthquake that never stops. (NYT, 10 October 2014)

\begin{tabular}{|l|l|l|}
\hline & $\begin{array}{c}\text { New York } \\
\text { Times }\end{array}$ & $\begin{array}{c}\text { New } \\
\text { York } \\
\text { Daily } \\
\text { News }\end{array}$ \\
\hline TSUNAMI/FLOOD & 14 & 3 \\
\hline FIRE & 6 & 3 \\
\hline STORM & 1 & 0 \\
\hline EARTHQUAKE & 1 & 0 \\
\hline
\end{tabular}

Table 4 - Number of occurrences of EBOLA AS A NATURAL CATASTROPHE according to the type of source domain

The aptness of the metaphor EBOLA AS A NATURAL CATASTROPHE stems from the shared features of the Ebola disease and natural catastrophes as having a natural source and having a potential to cause death. Nevertheless, the metaphor hides the contribution of social factors to the spread of the illness. Instead, the Ebola virus is portrayed as moving uncontrollably on its own.

\subsection{Warrior iconography}

\subsubsection{Villains}

The metaphoric representations of Ebola ascribe the role of a villain to the Ebola virus by portraying it as an aggressive, cruel enemy attacking people. In contrast, the non-metaphoric representations of Ebola rather allocate the blame for the spread of the disease to man-made factors. Table 5 reveals which social aspects are ascribed the responsibility for the spread of Ebola most frequently in each newspaper. Overall, the number of articles concerned with the discussion of social aspects to be blamed is substantially higher in the broadsheet newspaper than the tabloid.

\begin{tabular}{|ll|ll|}
\hline New York Times & & New York Daily News & \\
\hline government & 26 & healthcare system & 14 \\
ordinary Africans' attitudes & 22 & ordinary Africans' attitudes & 8 \\
local traditions & 21 & slow international aid & 7 \\
healthcare system & 20 & government & 5 \\
slow international aid & 14 & local traditions & 3 \\
infrastructure & 4 & infrastructure & 1 \\
\hline
\end{tabular}

Table 5 - Man-made factors allocated the blame for the spread of Ebola, with the number of articles which assign the role of culprit to these factors

As shown in Table 5 , the role of culprit is most frequently assigned to the government for mishandling the situation in The New York Times (example [4]) and to an inadequate healthcare system in the affected countries in The New York Daily News (example [5]). The second most frequent aspect ascribed the role of villain in both newspapers is ordinary Africans' attitude, the foregrounding of which partially constructs people in Africa as those to be blamed. Yet, rather than directly blaming the citizens themselves, the newspapers tend to depict their emotions or attitudes as the culprit, namely distrust (governments [...] have faced another dangerous obstacle: distrust among the local population), fear (health workers [...] are now battling two enemies: the unprecedented Ebola epidemic [...] and fear), disobedience and disrespect (the infection rate was rising [...] because of [the] lack of respect for the rigorous isolation measures), and denial and ignorance (denial and ignorance are part of the problem). Both newspapers also repeatedly allocate responsibility to local traditions, namely burial practices (example [6]). It is not only social factors in the affected African countries but also slow international aid that is blamed for the spread of the disease (the international response to the disease has been a failure; international community's slow recognition of the gravity of the crisis [...] contributed to delays in gearing up an effective response).

(4) The intensification of the spread of Ebola is a failure of governance. (NYT, 3 November 2014)

(5) The epidemic in West Africa, one of the world's poorest regions where crumbling healthcare systems are unable to cope [...]. (NYDN, 12 August 2014)

(6) Seventy percent of new cases here, Western officials said, are directly linked to 
traditional burials. (NYT, 27 November 2014)

Furthermore, although both newspapers explicitly indicate the existence of stigmatization of Ebola patients (as illustrated in examples (7) and [8]), the discursive strategies that they adopt in several instances implicitly depict those infected by Ebola as wrongdoers. Such strategies include the ascription of the semantic role of agent in the spread of the disease in 19 instances in The New York Times and 8 in The New York Daily News: sick and dead villagers are infecting others; two mourners at the grandmother's funeral took the virus home to their village; the little girl probably exposed dozens of people to the virus; the Liberian man [...] brought the virus to the United States.

(7) Outside the zone, hysteria over Ebola has led to the collective stigmatization of a big chunk of the African continent. (NYT, 17 September 2014)

(8) Today, people from the continent of Africa are being stigmatized because of Ebola. (NYDN, 15 October 2014)

The negative portrayal of ordinary Africans is intensified in The New York Times by the newspaper reproducing negative stereotypes concerning the Third World, even though it explicitly indicates the danger of stereotyping Africans in one of the articles (example [9]).

(9) We must also beware of 'us' and 'them,' a mentality that locks people into rigid identity groups and reduces all Africans - or all West Africans, or some smaller, national or local group - to a stereotype. (UN commissioner for human rights, NYT, 16 October 2014)

The New York Times recurrently assigns negative attributes to Africans and foregrounds problems in African countries, repeatedly portraying West Africans as angry (angry young men hurled rocks; the angry crowd descended on them), violent (violence directed at health workers; the reaction was swift and violent), corrupt (countless others have used a different method: bribing their way out) and hostile (to minimize contact with an often hostile community; the charity's doctor [...] was met with indifference or hostile stares). The newspaper depicts the countries affected by Ebola as chaotic (an even more chaotic situation in Liberia than had been thought; a quarantine sows social chaos), with many problems stereotypically assigned to the Third World, such as crime and drugs (crime keeps rising, and so has the use of crack cocaine). Positive attributes and actions of West Africans tend to be backgrounded or absent. Such a foregrounding of negative stereotypes is not characteristic for The New York Daily News; yet, as shown in the next section, the tabloid newspaper devotes little space to the situation in Africa in comparison to that in the United States.

The analysis reveals that the combination of metaphoric and non-metaphoric representations of Ebola brings about a complexity with respect to the discursive ascription of blame for the spread of the disease and the corresponding allocation of the role of villain. Multiple factors, both natural and social, including the Ebola virus, the government, the healthcare system, the attitudes of Africans, the international response, and Ebola victims themselves, are ascribed responsibility. Furthermore, it is revealed that The New York Times partially demonizes people in Africa by reproducing negative stereotypes of Africans as angry, violent, hostile and problematic.

\subsubsection{Victims}

Those infected by the Ebola virus are recurrently referred to as Ebola victims. A common discursive strategy used to represent this group of social actors is impersonalization (i.e., a depiction of human beings by means that do not include the semantic feature "human") (van Leeuwen, 2010), namely the adoption of expressions such as cases, caseload, deaths, death toll, fatalities and infections, and the use of numbers (Ebola has killed 1,900; Ebola Could Strike 20,000). Such a portrayal is effective in depicting the impact of the disease, yet, it distances readers from the victims as human beings.

Ordinary Africans infected with Ebola are generally denied agency in the newspaper discourse; for instance, they are rarely depicted as agents in the fight against the disease, as discussed in section 2.1.1. The exception is the ascription of the agentive role in the spread of the disease (see section 2.2.1). They tend to be portrayed as passive and helpless, with the focus repeatedly placed on a graphic description of their body position and body parts (implying a lack of volition) and symptoms of the illness: Sory Sesay, 2, lay face down on a bench at his 
home, an arm dangling, his eyes open, listless and apathetic; a patient, still alive but rigid, motionless and prostrate; she curled up on the floor, her jeans splotched with dried black vomit; a patient, sweating and heavily soiled, had collapsed in the corridor; and a solidly built young man sprawled out on the floor all night, his right hand twisted in an awkward clench. Such a portrayal, balancing on the verge of sensationalism, runs the risk of making readers merely absorbed in the horror of the disease, hindering identification with the victims or contemplation of their situation.

Furthermore, ordinary Africans infected by the virus are rarely given a voice in the newspapers. Although around 40 percent of those infected by Ebola have survived, the direct quotations of African victims conveying their experience occur only in 10 articles (out of 218 studied) in The New York Times and 1 article (out of 282 studied) in The New York Daily News. The overall absence of the establishment of Africans infected by Ebola as sovereign agents prevents a construction of the reflexive identification between readers and the victims.

A group of victims foregrounded in both newspapers (examples (10) and [11]) is healthcare workers, both African and international (a second leading Sierra Leone doctor has succumbed to the Ebola epidemic; a 29-year-old British nurse [...] contracted the disease while working in Sierra Leone). Healthcare workers are singled out as Ebola victims in 57 articles (26 percent) in The New York Times and 109 articles (39 percent) in The New York Daily News. These victims tend to be individualized ( $\mathrm{Dr}$. Modupeh Cole, 56 died Wednesday), with background information about them supplied in the articles, allowing the readers to share a sense of common humanity with them. In addition, healthcare workers are often portrayed as heroes, as shown in next section.

(10) The Ebola outbreak sweeping West Africa has killed more than 2,200 people and has taken a particularly high toll on health care workers. (NYDN, 9 September 2014)

(11) Ebola has devastated the economies of three fragile West African countries, spread panic and fear across much of the world, and taken a particularly devastating toll on health workers treating Ebola patients. (NYT, 18 September 2014)
An idiosyncratic feature of The New York Daily News is a disproportionate foregrounding of the experience of the Ebola victims of American nationality and a backgrounding of the experience of victims from West African countries. The main topic of only 20 percent of the articles on Ebola (in contrast to 63 percent in The New York Times) concerns the situation in African countries, with the remaining articles mainly focusing on American victims, the preparedness of the United States for the disease and the role of the United States as a helper to affected African countries. In contrast to Ebola victims of African nationalities, those of American nationality are individualized, with detailed background information about them provided, are given a voice (nineteen articles include direct quotations of their experiences, in contrast to one article quoting an African victim), are portrayed as "good" victims with their positive attributes highlighted (the resilient nurse; a selfless man; kind, helpful, hardworking young man) and are given agency (now the doctor [...] is fighting for his life against the deadly virus; she's working real hard to get through this). By prioritizing Americans and their experiences and making African suffering, to a large extent, invisible, The New York Daily News assigns the experiences of Africans a position of lesser importance and reproduces thus the First World-Third World power asymmetry.

\subsubsection{Heroes}

Bringing a positive element and an aspect of triumph into the negative accounts of Ebola, both newspapers adopt the image of HERO. This role is explicitly assigned to healthcare workers, both African and international, in 6 instances in The New York Times and 14 instances in The New York Daily News, including the following: Dr. Sheik Humarr Khan [...] was praised as a national hero; some of the most heroic work has been done by the group Doctors Without Borders; our team met heroic doctors and nurses at their wits end. The position of hero is also implicitly assigned to the United States, the help of which is emphasized in both newspapers, with President Obama placing the country into a leadership position in the international fight against Ebola (the United States must lead the international effort in containing the spread of Ebola in Africa). A patronizing ideology is illustrated in example (12), which metaphorically portrays 
the United States as being in possession of Liberia.

(12) That leaves Liberia, with its historic ties to America's antebellum era, in the United States' hands. (NYT, 12 September 2014)

\section{Conclusion}

The analysis of metaphoric conceptualizations of Ebola in two liberal American newspapers, The New York Times and The New York Daily News, has revealed the newspapers' reliance predominantly on a single conceptual metaphor of EBOLA AS WAR, even though the military framing of diseases has been criticized by some scholars in the past for stigmatizing the disease and inevitably extending the stigmatization to carriers of the disease as well (Sontag, 1978; 1989; Larson, Nerlich and Wallis, 2005). Only two other alternative metaphors of Ebola, EBOLA AS AN ANIMATE/HUMAN BEING and EBOLA AS A NATURAL CATASTROPHE, have been found in the corpus, making the variety of employed metaphors limited in contrast, for instance, to the complex metaphoric portrayal of cancer in the British press, adopting ten different metaphors of the disease (Camus, 2009). Emotionally laden, metaphoric portrayals of Ebola as war and a cruel and violent animate/human being have the potential to evoke a range of emotions, from fear to pity and empathy, towards Ebola victims. The ideological function of all three metaphoric themes detected in the corpus is the allocation of the role of culprit solely to the virus, depicted as acting with volition and spreading of its own accord. This stands in contrast to non-metaphoric discursive allocations of blame for the situation in Africa, which assign responsibility to man-made factors, including the governmental and international responses, weak healthcare systems, attitudes of Africans, local traditions and poor logistics.

Ordinary Africans infected with Ebola have been shown to be generally represented as agentless and voiceless. The empowering potential of the military metaphor for victims is not realized in the newspaper discourse, as ordinary African victims (in contrast to healthcare workers) are rarely credited with the role of "fighter". The cases of African Ebola victims occupying an agentive position are commonly those of the agents of processes denoting a spread of the disease (such as carry the virus and take the virus), implicitly assigning to them the role of a culprit. The portrayal of people in Africa as those to be blamed is further intensified by the foregrounding of negative attitudes of Africans in both newspapers as responsible for the spread of Ebola. In addition, African victims tend to be impersonalized (referred to as cases and deaths), and when individualized, the focus is placed on a graphic depiction of their symptoms and body positions implying passivity and helplessness. The New York Daily News, furthermore, backgrounds African victims, prioritizing Americans. The portrayal of African sufferers as agentless, voiceless, helpless and even invisible corresponds to the findings of previous studies, namely Fair (1996) and Fair and Parks (2001), and runs counter to the initial hypothesis of this study expecting the avoidance of such a portrayal in liberal newspapers, mainly due to globalization, the political orientation of the newspapers and enlightenment of Western journalists with regard to Africa's image.

The findings of recent studies detecting a change towards a more positive portrayal of Africa in Western media (Scott, 2009; Ibelema, 2014; Nothias, 2014) have not been confirmed by the present study. On the contrary, it has been revealed that negative attributes stereotypically assigned to the Third World, namely violence, problems, chaos, anger, hostility and crime, are repeatedly foregrounded in the depiction of West African countries in The New York Times. The foregrounding of negative characteristics is less prominent in The New York Daily News; yet, the newspaper degrades the situation in Africa by paying minimal attention to it in comparison with the situation in the United States.

Since news consumption is an active process (Macdonald, 2003) with readers not just passively absorbing the text but actively interpreting it by drawing on their knowledge, experiences and beliefs, the present study would benefit from audienceoriented research. Nonetheless, the merit of the text-oriented approach adopted in this paper stems from the fact that textual cues themselves largely influence and constrain the interpretation process and reader positions (Fairclough, 1995). The present study revealed that both The New York Times and The New York Daily News fail to depict Ebola victims from African countries as sovereign agents, which in effect impedes 
readers from establishing a relationship of reflexive identification with them.

\section{References}

BOLTANSKI, L., 1999. Distant suffering: Morality, media and politics. Cambridge: Cambridge University Press.

BROOKES, H.J., 1995. 'Suit, tie and a touch of juju' - The ideological construction of Africa: A critical discourse analysis of news on Africa in the British press. Discourse and Society, vol. 6, no. 4, pp. 461-494.

CAMUS, J.T.W., 2009. Metaphors of cancer in scientific popularization articles in the British press. Discourse Studies, vol. 11, no. 4, pp. 465-495.

CHARTERIS-BLACK, J., 2004. Corpus approaches to critical metaphor analysis. Basingstoke:

Palgrave Macmillan.

CHOULIARAKI, L., 2006. The spectatorship of suffering. London: Sage.

CLARKE, J.N., 1992. Cancer, heart disease and AIDS: What do the media tell us about these diseases? Health Communication, vol. 4, no. 2, pp. 105-120.

CLOW, B., 2001. Who's afraid of Susan Sontag? Or, the myths and metaphors of cancer Reconsidered. Social History of Medicine, vol. 14, no. 2, pp. 293-312.

DE B'BÉRI, B.E. and LOUW, P.E., 2011 . Afropessimism: A genealogy of discourse. Critical Arts, vol. 25, no. 3, pp. 335-346.

ENGELHARDT, J. von and JANSZ, J., 2014. Challenging humanitarian communication: An empirical exploration of Kony 2012. International Communication Gazette, vol. 76, no. 6, pp. 464-484.

FAIR, J.E., 1996. The body politic, the bodies of women, and the politics of famine in U.S. television coverage of famine in the Horn of Africa. Journalism and Mass Communication Monographs, vol. 158, pp. 1-41.

FAIR, J.E. and PARKS, L., 2001. Africa on camera: Television news coverage and aerial imaging of Rwandan refugees. Africa Today, vol. 48, no. 2, pp. 34-57.

FAIRCLOUGH, N., 1992. Discourse and social change. Cambridge: Polity Press. FAIRCLOUGH, N., 1995. Media discourse. London: Edward Arnold.

GOLAN, G.J., 2008. Where in the world is Africa? Predicting coverage of Africa by US television networks. The International Communication Gazette, vol. 70, no. 1, pp. 41-57. HAMMOND, P., 2007. Framing post-Cold War conflicts: The media and international intervention. New York: Twayne Publishers.

HARCUP, T. and O'NEILL, D., 2001. What is news? Galtung and Ruge revisited. Journalism Studies, vol. 2, no. 2, pp. 261-280.

HART, CH. and LUKEŠ D. (eds), 2007. Cognitive linguistics in critical discourse analysis: Application and theory. Newcastle, UK: Cambridge Scholars Publishing.

HART, CH., 2011 . Force-interactive patterns in immigration discourse: A cognitive linguistic approach to CDA. Discourse and Society, vol. 22, no. 3, pp. 269-286.

HAWK, B. (ed), 1992. Africa's media image. New York: Praeger.

HAWKINS, B., 2001. Ideology, metaphor and iconographic reference. In: R. Dirven, R. Frank and C. Ilie, eds. Language and ideology, volume II: Descriptive cognitive approaches.

Amsterdam: John Benjamins Publishing, pp. 27-50.

HUNTER-GAULT, CH., 2006. New news out of Africa: Uncovering Africa's renaissance. New York: Oxford University Press.

IBELEMA, M., 2014. "Tribal fixation" and Africa's otherness: Changes and resilience in news coverage. Journalism and Communication Monographs, vol. 16, no. 3, pp. 162-217.

JOYE, S., 2010. News discourses on distant suffering: A critical discourse analysis of the 2003 SARS outbreak. Discourse and Society, vol. 21 , no. 5, pp. 586-601.

KOLLER, V., 2004. Metaphor and gender in business media discourse: A critical cognitive study. Basingstoke: Palgrave Macmillan.

KYRIAKIDOU, M., 2015. Media witnessing: Exploring the audience of distant suffering. Media, Culture and Society, vol. 37, no. 2, pp. 215-231.

LAKOFF, G. and JOHNSON, M., 1980. Metaphors we live by. Chicago: University of Chicago Press.

LAKOFF, G. and JOHNSON, M., 1999. Philosophy in the flesh: The embodied mind and its challenge to Western thought. New York: Basic Books. 
LARSON, B.M.H., NERLICH, B. and WALLIS, P., 2005. Metaphors and biorisks: The war on infectious diseases and invasive species. Science Communication, vol. 26, no. 3, pp. 243268.

MACDONALD, M., 2003. Exploring media discourse. London: Arnold.

MEYERS, L., FRAWLEY, T., GOSS, S. and KANG, Ch., 2015. Ebola virus outbreak 2014: Clinical review for emergency physicians. Annals of Emergency Medicine, vol. 65, no. 1, pp. 101-108. NOTHIAS, T., 2014. 'Rising', 'hopeful', 'new': Visualizing Africa in the age of globalization. Visual Communication, vol. 13, no. 3, pp. 323-339.

PATTON, C., 1990. Inventing AIDS. London: Routledge.

PETSKO, G., 2001. The Rosetta stone. Genome Biology, vol. 2, no. 5, pp. 1-2.

REISFIELD, G. and WILSON, G., 2004. Use of metaphor in the discourse on cancer. Journal of Clinical Oncology, vol. 22, no. 19, pp. 4024-4027.

SAID, E.W., 1978. Orientalism. New York: Vintage.

SANDAHL, C., 2001. Performing metaphors: AIDS, disability, and technology. Contemporary Theatre Review, vol. 11, no. 3-4, pp. 49-60.

SCOTT, M., 2009. Marginalized, negative or trivial? Coverage of Africa in the UK press.

Media, Culture and Society, vol. 31, no. 4, pp. 533-557.

SCOTT, M., 2014. The mediation of distant suffering: An empirical contribution beyond television news texts. Media, Culture and Society, vol. 36, no. 1, pp. 3-19.

SEMINO, E., 2008. Metaphor in discourse. Cambridge: Cambridge University Press.

SILVERSTONE, R., 2007. Media and morality: On the rise of the mediapolis. Cambridge: Polity Press.

SMITH, T.C., 2006. Deadly diseases and epidemics: Ebola. Philadelphia: Chelsea House.

SONTAG, S., 1978. Illness as metaphor. New York: Farrar, Straus and Giroux.

SONTAG, S., 1989. AIDS and its metaphors. New York: Farrar, Straus and Giroux.

TRČKOVÁ, D., 2014. Representations of natural catastrophes in newspaper discourse. Brno:

Masaryk University.

VAN DIJK, T.A., 1988. News as discourse. Hillsdale, NJ: Lawrence Erlbaum.

VAN DIJK, T.A., 1993. Principles of critical discourse analysis. Discourse and Society, vol. 4, no. 2, pp. 249-283.

VAN LEEUWEN, T., 2008. Discourse and practice: New tools for critical discourse analysis.

Oxford: Oxford University Press.

WALLIS, P. and NERLICH, B., 2005. Disease metaphors in new epidemics: The UK media

framing of the 2003 SARS epidemic. Social Science and Medicine, vol. 60, pp. 2629-2639.

WEISS, G. and WODAK, R. (eds), 2003. Critical discourse analysis: Theory and

interdisciplinarity. Basingstoke: Palgrave Macmillan.

WODAK, R., 2006. Mediation between discourse and society: Assessing cognitive approaches in CDA. Discourse Studies, vol. 8, no. 1, 179-190.

WODAK, R. and MEYER, M. (eds), 2009. Methods of critical discourse analysis. 2nd ed.

London: Sage.

Corpus material

The New York Daily News [online] [Accessed 2 January 2015].

Available at:

http://www.nydailynews.com/

The New York Times [online] [Accessed 2 January 2015].

Available at:

http://www.nytimes.com/

\section{Author's address and contact details}

Mgr. Dita Trčková, Ph.D.

Department of Modern Languages and Literatures

Faculty of Humanities, Tomas Bata University in Zlín

Mostní 5139, 76001 Zlín, Czech Republic

Phone: +420576032207

Email: trckova@fhs.utb.cz 